\title{
Antigen-Presenting Activity of Non-Langerhans Epidermal Cells in Contact Hypersensitivity Reactions
}

\author{
O. BAADSGAARD, S. LISBY, C. AVNSTORP, O. CLEMMENSEN \& \\ G. LANGE-VEJLSGAARD
}

Laboratory of Immunology, Department of Dermatology, Bispebjerg Hospital, and Department of Dermatology, Gentofte Hospital, University of Copenhagen, Denmark; and Department of Dermatology, University of Michigan Medical School, Ann Arbor, Michigan, USA

\begin{abstract}
Baadsgaard, O., Lisby, S., Avnstorp, C., Clemmensen, O. \& Lange-Vejlsgaard, G. AntigenPresenting Activity of Non-Langerhans Epidermal Cells in Contact Hypersensitivity Reactions. Scand. J. Immunol. 32, 217-224, 1990

Despite the critical role of the Langerhans cells in the induction of contact hypersensitivity reactions, non-Langerhans antigen-presenting cells in already sensitized individuals may play a role in the elicitation phase of a contact hypersensitivity reaction. Following epicutaneous challenge with antigens, the number of $\mathrm{CDI}^{+} \mathrm{DR}^{+}$epidermal Langerhans cells increased in a time-dependent way and, concomitantly, $\mathrm{CDI}{ }^{-} \mathrm{OKM} 5^{+} \mathrm{DR}{ }^{+}$epidermal non-Langerhans cells appeared. In parallel with this, the capacity of epidermal cells to present both alloantigens and auto/nominal antigens increased, and 4 days after initiation of the contact hypersensitivity reactions $33-53 \%$ of the epidermal antigen-presenting capacity was due to $\mathrm{CDI}^{-}$nonLangerhans antigen-presenting cells. Thus, contact hypersensitivity skin reactions are accompanied by the appearance of non-Langerhans antigen-presenting cells capable of presenting both alloantigens and auto/nominal antigens.
\end{abstract}

Ole Baadsgaard, MD, University of Copenhagen, Department of Dermatology, Gentofte Hospital, DK-2900 Hellerup, Denmark

In normal human epidermis the Langerhans cell is the only cell type capable of presenting antigens to $\mathrm{T}$ lymphocytes, thus eliciting $\mathrm{T}$-cell activation [7, 8, 29]. Human epidermal Langerhans cells express CD1 [12] and major histocompatibility complex (MHC) class II molecules [16, 22]. The Langerhans cells are critical for the induction of delayed-type hypersensitivity reactions in mice $[21,31,32]$. Thus, sensitization through murine skin depleted of Langerhans cells results in the induction of antigen-specific tolerance rather than a contact hypersensitivity reaction $[24,30$. 31, 32]. While the Langerhans cells are critical for the induction of the immune response in contact hypersensitivity reactions, non-Langerhans antigen-presenting cells may play a role in the effector phase of the immune response. This is supported by the findings in sensitized humans which demonstrate that irradiation of the skin with up to four minimal erythema doses (MED) of UVB. a dose that normally efficiently abrogates the function of epidermal Langerhans cells, had no effect on subsequent challenge with contact allergens [27]. This could be the result of rapid recovery of functional Langerhans cell activity. However, since UVB irradiation induces the appearance of $\mathrm{CD}^{-}{ }^{-} \mathrm{DR}^{+}$epidermal non-Langerhans cells $[1-3,5,10,11]$, this cell type may, in addition to the Langerhans cells, be capable of presenting antigens to primed $\mathrm{T}$ cells, eliciting $\mathrm{T}$ cell activation. This observation prompted us to study the function and type of epidermal antigenpresenting cells present in the skin at various time points following initiation of allergic skin reactions. It was found that $\mathrm{CDI}-\mathrm{OKM} 5^{+} \mathrm{DR}{ }^{+}$ epidermal non-Langerhans antigen-presenting cells appear during hypersensitivity reactions and were in two experiments responsible for up to 33 and $53 \%$ of the total epidermal antigen-presenting capacity. Whether these cells function to up- 
or down-regulate the immune function response is unknown.

\section{MATERIALS AND METHODS}

Patients. Nine patients with contact allergy verified by patch test participated in the study after giving informed consent. Each patient was challenged with serial dilutions of relevant hapten in order to determine a concentration of hapten which induced erthema and infiltration but not vesiculation (i.e. + to ++ reactions). The haptens used were primin, nickel sulphate, sodium dichromate, ethylene diaminedihydrochloride, yarrow, and clioquinol. Twelve-millimetre Finn chambers were used for patch testing. Four patches with haptens in petrolatum were applied on the volar forearm at least $5 \mathrm{~cm}$ apart, at 1,3,4, and 7 days prior to investigation. In addition, a chamber filled with petrolatum was used as vehicle control and applied for 48 h 4 days prior to the study. All patches were removed after 24 or 48 h.

Preparation of epidermal cell suspensions. Suction blister-derived epidermal cells were obtained from unchallenged areas and from sites challenged with vehicle (petrolatum) or hapten in petrolatum. Epidermal sheets were floated dermal side down on $0.25 \%$ trypsin (U.S. Biochemical Corp., Cleveland, Ohio, USA) in Dulbecco's phosphate-buffered saline (PBS) for $40 \mathrm{~min}$ at $37^{\circ} \mathrm{C}$. Trypsinized epidermal sheets were transferred to $0.025 \%$ DNAse (Sigma, St Louis, Mo., USA) in Dulbecco's PBS, teased into a cell suspension, and were filtered through nylon gauze to achieve a single-cell suspension. Fetal bovine serum (FBS) was added to inactivate the trypsin, and the cells were washed three times in PBS containing 10\% FBS. Epidermal cells were then resuspended in RPMI 1640 with added antibiotics, glutamine, and $10 \%$ human $\mathrm{AB}$ serum from non-transfused male donors. Cell viability (trypan blue exclusion) was monitored in haemocytometers and was more than $85 \%$.

Epidermal cell-surface membrane staining. Cell suspensions were stained simultaneously with biotin-conjugated anti-HLA-DR (Becton Dickinson, Sunnyvale, Calif., USA) and either fluorescein isothiocyanate (FITC)-conjugated anti-HLel (CD45) (Becton Dickinson), OKT6 (CDI), OKM5 (Ortho Immunodiagnostics, Raritan, NJ, USA), or the appropriate isotype controls for $45 \mathrm{~min}$ at $4{ }^{\circ} \mathrm{C}$. The cells were then washed three times in Dulbecco's PBS containing $\mathrm{NaN}_{3}$ and bovine serum albumin (BSA), and incubated with streptavidin-conjugated Texas red (Bethesda Research Labs, Bethesda, Md, USA) for $30 \mathrm{~min}$ at $4{ }^{\circ}$ C. The cells were washed, and propidium iodide was added to monitor viability. A total of 1000 cells was counted using a Zeiss microscope equipped with epifluorescence. The result was expressed as the percentage \pm SEM of labelled viable cells (negative for propidium iodide) of total cell count. A three-step staining procedure was then applied, as previously described [21]. The cell suspensions were briefly incubated with unconjugated monoclonal antibody for $45 \mathrm{~min}$ at $4 \mathrm{C}$. A second incubation was performed using human serumabsorbed rhodamine-conjugated rabbit anti-mouse IgG (Dacopatts, Copenhagen, Denmark) diluted in
PBS containing 10\% vol/vol human AB serum. Finally, a third incubation was performed using normal mouse sera (in excess to occupy residual anti-IgG sites) and FITC-conjugated monoclonal antibody.

Depletion of leucocytes contained within the epidermal cell suspension. Leucocytes were depleted from the epidermal cell suspensions using magnetic beads coated with anti-mouse IgG (Dynal As, Skøyen, Norway). Epidermal cells pretreated with anti-HLA-DR, antiLeu6 (Becton Dickinson), or a combination of the two antibodies were incubated for $30 \mathrm{~min}$ at $4 \mathrm{C}$, on a rotating rack; cells bound to beads were removed by exposure to a magnet, and the cell subsets remaining in suspension were harvested.

Preparation of peripheral blood mononuclear cells. Allogeneic or autologous peripheral blood mononuclear cells (MNC) were isolated from heparinized venous blood by Ficoll-Hypaque density-gradient centrifugation. MNC at the interface were collected, washed three times, and resuspended in RPMI 1640 with added antibiotics, glutamine, and $10 \%$ human $\mathrm{AB}$ serum.

Isolation of $T$ cells. Human peripheral blood MNC were incubated on plastic for $1 \mathrm{~h}$ at $37^{\circ} \mathrm{C}$. The macrophage-depleted non-plastic adherent MNC were then rosetted with $1 \%$ 2-aminoethyl-isothiouronium bromide hydrobromide-treated sheep red blood cells. A second Ficoll-Hypaque density-gradient centrifugation was performed to obtain non-rosetting B and null cells at the interface $\left(\mathrm{E}^{-}\right)$and rosetted $\mathrm{T}$ lymphocytes from the pellet $\left(\mathrm{E}^{+}\right)$. The $\mathrm{E}^{+}$-cell fraction contained more than $95 \%$ T lymphocytes as determined by staining with fluoresceinated anti-Leul (CD5) (Becton Dickinson, Mountain View, Calif., USA). The T cells were further depleted of antigen-presenting cells by complement lysis of HLA-DR + leucocytes.

Proliferative response of $T$ lymphocytes to allogeneic or autologous epidermal cells. Allogeneic or autologous epidermal cell-lymphocyte in vitro reactions were performed in round-bottomed microtitre wells in $0.2 \mathrm{ml}$ RPMI 1640 supplemented with $10 \%$ AB serum, glutamine, penicillin, and streptomycin. Various numbers of gamma-irradiated (2000 rad) epidermal cells were added to 50,000 or 100,000 responder allogeneic MNC or autologous T cells. The cultures were pulsed after 6 days with $1 \mu \mathrm{Ci}$ of $\left[{ }^{3} \mathrm{H}\right] \mathrm{TdR}$ per well, harvested $18 \mathrm{~h}$ later on a Nunc cell harvester (Tecknunc, Roskilde, Denmark), and $\left[{ }^{3} \mathrm{H}\right] \mathrm{TdR}$ incorporation was measured using a liquid scintillation counter.

Statistical analysis, Repeated-measures analyses of variance was used for statistical evaluation of the number of antigen-presenting cells. Student's $t$-test was used for evaluation of the $\left[{ }^{3} \mathrm{H}\right] \mathrm{TdR}$ uptake by stimulated $\mathrm{T}$ cells.

\section{RESULTS}

\section{Epidermal cells from contact hypersensitivity reactions contain increased numbers of $C D I^{+} D R^{+}$non-Langerhans cells and $\mathrm{CDI}^{-} \mathrm{OKM} 5^{+} \mathrm{DR}^{+}$non-Langerhans cells}

Occlusion of the skin with petrolatum for $48 \mathrm{~h}$ induced the appearance of an increased number 


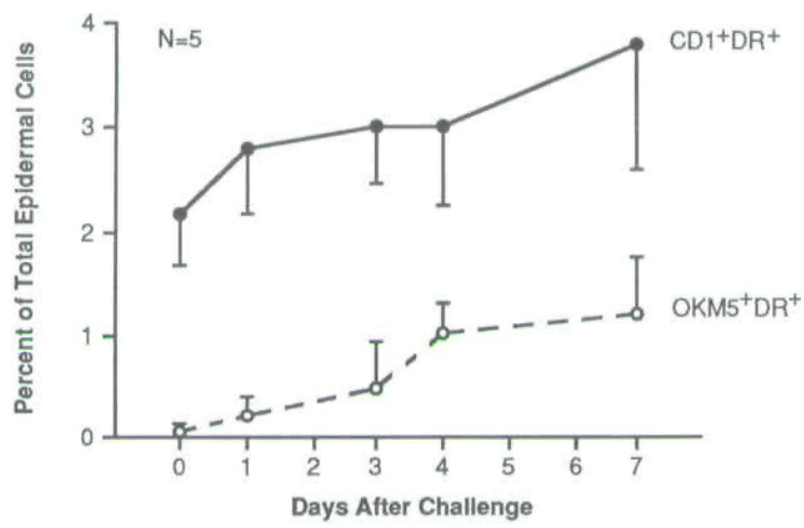

FiG. 1. Five patients with verified allergic contact hypersensitivity were challenged with hapten $1,3,4$, and 7 days prior to investigation. The number of $\mathrm{CDI}^{+} \mathrm{DR}^{+}$epidermal Langerhans cells and the number of $\mathrm{OKM} 5^{+} \mathrm{DR}{ }^{+}$epidermal non-Langerhans cells were determined from hapten-challenged sites and from a vehicle(petrolatum) challenged site $(0)$. In all five patients tested, the number of Langerhans cells increased in a time-dependent fashion, and concomitantly non-Langerhans $\mathrm{OKM} 5^{+} \mathrm{DR}{ }^{+}$epidermal cells appeared. Results are expressed as mean values of five individuals \pm SEM.

of $\mathrm{CDI}^{+}{ }^{+} \mathrm{DR}+$ Langerhans cells in the absence of detectable numbers of $\mathrm{CDI}^{-} \mathrm{DR}^{+}$epidermal cells. Because of this immunostimulatory effect of the vehicle (petrolatum occlusion), all test results were compared with vehicle controls and not with unchallenged skin. Challenged skin from previously sensitized persons demonstrated an increased number of potential epidermal antigenpresenting cells in 5 out of 5 individuals tested $(n=5)(P \leq 0.02)$. Statistical significance was seen already at day 3 . The number of $\mathrm{CD}^{+}{ }^{+} \mathrm{DR}^{+}$ Langerhans cells and $\mathrm{CDI}^{-} \mathrm{DR}^{+} / \mathrm{OKM}^{+}{ }^{+} \mathrm{DR}{ }^{+}$ non-Langerhans epidermal cells was assessed in each individual following vehicle control and 1,3, 4 , and 7 days after challenge. The number of $\mathrm{CD1}+\mathrm{DR}^{+}$Langerhans cells increased in a timedependent fashion in all individuals tested from day 1 (mean $2.2 \pm 0.06 \%, n=5$ ) to a maximum at day 7 (mean $3.7 \pm 1.4 \%, n=5$ ). Concomitantly, the number of $\mathrm{CD}^{-}{ }^{-} \mathrm{DR}^{+} / \mathrm{OKM} 5^{+} \mathrm{DR}^{+}$nonLangerhans epidermal cells also increased from the vehicle control baseline (mean $0 \%+0, n=5$ ) to a maximum at day 7 (mean $1.3 \pm 0.6 \%, n=5$ ) (Fig. 1). The number of $\mathrm{CDl}^{-} \mathrm{DR}^{+}$epidermal cells was equal to the number of $\mathrm{OKM} 5^{+} \mathrm{DR}{ }^{+}$ epidermal cells, and both the OKM5 ${ }^{+}$epidermal cells and the $\mathrm{DR}^{+}$epidermal cells coexpressed HLel, indicating that all $\mathrm{CDI}^{-} \mathrm{DR}^{+}$
OKM $5+{ }^{+} \mathrm{DR}+$ epidermal cells were bone marrowderived leucocytes and that no $\mathrm{DR}^{+}$or $\mathrm{OKM} 5^{+}$ keratinocytes were present. These data also indicate that $\mathrm{CDI}^{-} \mathrm{DR}^{+}$epidermal cells coexpress OKM5. Furthermore, only a minority $(35 \pm 2 \%$, $n=2)$ of the $\mathrm{OKM}^{+}$epidermal cells coexpressed OKM1, indicating that the majority of the $\mathrm{OKM} 5^{+} \mathrm{DR}^{+}$epidermal cells are OKM1 ${ }^{-} \mathrm{OKM}^{+}$.

\section{Epidermal cells from contact hypersensitivity reactions demonstrate increased capacity to stimulate autologous $T$ cells}

In order to determine whether the increased number of Langerhans cells and non-Langerhans $\mathrm{CD} 1-\mathrm{OKM}^{+}{ }^{+} \mathrm{DR}^{+}$epidermal cells resulted in an enhanced capacity of epidermal cells to activate autologous $\mathrm{T}$ cells, epidermal cell lymphocyte reactions were performed. Increasing numbers of epidermal cells from a petrolatum-challenged area and from sites challenged with hapten 1,3,4, and 7 days before were added to antigen-presenting cell-depleted autologous T cells. At all epidermal cell concentrations tested from 10,000 to 160,000 , primin- $(0.01 \%$ in petrolatum $)$ challenged epidermal cells demonstrated a timedependent increase in the capacity to activate 


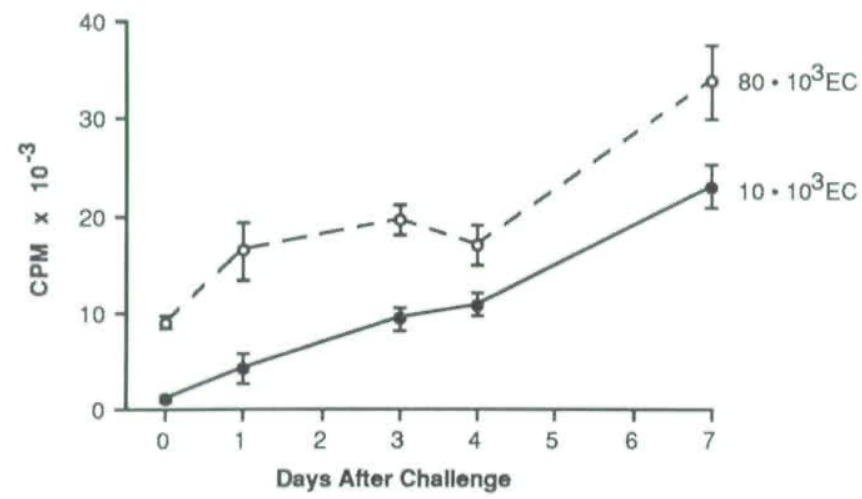

FiG. 2. Epidermal cells in suspension were obtained from petrolatumchallenged skin $(0)$ and from skin challenged with hapten 1, 3, 4, and 7 days prior to investigation. One hundred thousand autologous $\mathrm{T}$ cells were stimulated with 10,000 (suboptimal number) and 80,000 (optimal number) gamma-irradiated epidermal cells, and the resulting T-cell proliferation was measured as $\left[{ }^{3} \mathrm{H}\right] \mathrm{TdR}$ incorporation. Results are expressed as mean cpm \pm SEM of triplicate wells from a representative experiment.

autologous T cells (Fig. 2.). Similar results were obtained in another patient using nickel sulphate. Results from the patient challenged with nickel sulphate on day 4 are shown in Fig. 5.

\section{Contact hypersensitivity reactions result in an increased capacity of epidermal cells to activate allogeneic $T$ cells}

The increased capacity of hapten-challenged epidermal cells to activate autologous $\mathrm{T}$ cells could be the result of either an increased number of antigen-presenting cells or increasing presentation of processed hapten to the primed autologous $T$ cells. To determine whether the challenged skin actually demonstrated an increased functional antigen-presenting capacity, allogeneic epidermal cell lymphocyte reactions were performed since this reaction is not affected by the presence of nominal antigen.

Hapten-challenged epidermal cells in 5 out of 5 individuals tested demonstrated enhanced capacity to activate allogeneic $\mathrm{T}$ cells relative to vehicle-challenged epidermal cells (Table I and Fig. 3). The mean percentage increases compared with vehicle-challenged control values at an epidermal cell concentration of 40,000 is shown in Table I $(n=5, P \leq 0.05$, Student's $t$ test). The increase was seen in all patients tested indepen-
TABLE I. The percentage increase in $\left[{ }^{3} \mathrm{H}\right] \mathrm{TdR}$ uptake by allogeneic MNC stimulated with hapten-challenged skin relative to MNC stimulated with vehicle-challenged control skin 4 and 7 days after challenge in five different patients

\begin{tabular}{llcc}
\hline Patient & \multicolumn{1}{c}{ Hapten } & $\begin{array}{c}\text { Day 4* } \\
(\%)\end{array}$ & $\begin{array}{c}\text { Day 7 } \\
(\%)\end{array}$ \\
\hline 1 & Yarrow & $190 \pm 8$ & $168 \pm 7$ \\
2 & Ethylene & & \\
& diaminedihydrochloride & $159 \pm 8$ & $172 \pm 11$ \\
3 & Clioquinol & $121 \pm 4$ & $108 \pm 8$ \\
4 & Nickel sulphate & $161 \pm 20$ & ND \\
5 & Sodium dichromate & $113 \pm 10$ & ND \\
\hline
\end{tabular}

* $P \leq 0.05$.

ND, not determined.

dent of the hapten used. However, the increase was less than when autologous $\mathrm{T}$ cells were used as responder cells. Furthermore, the allogeneic reaction peaked at day 3 , whereas the autologous reaction was still increasing 7 days after hapten challenge.

Irrespective of these differences, hapten-challenged skin demonstrated increased capacity to present not only nominal and/or autoantigens but also alloantigens, and thus an increased function of antigen-presenting cells. 


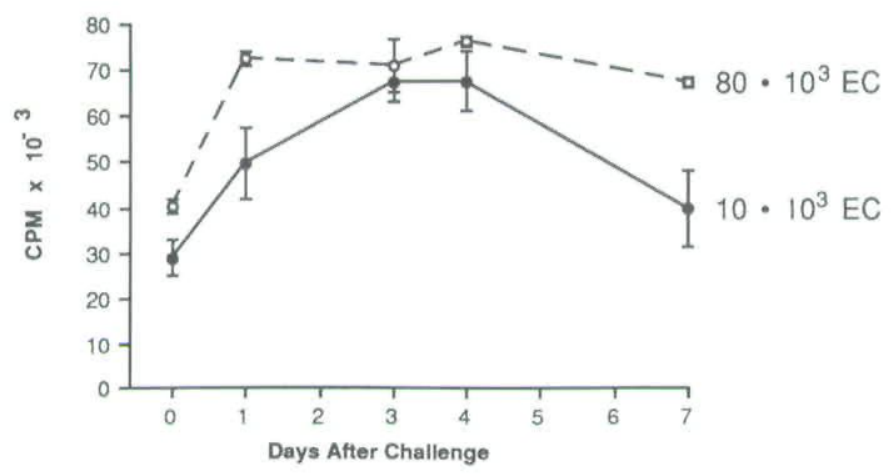

FIG. 3. Epidermal cells in suspension were obtained from petrolatumchallenged skin $(0)$ and from skin challenged with hapten $1,3,4$, and 7 days prior to investigation. Ten thousand (suboptimal number) and 80,000 (optimal number) gamma-irradiated epidermal cells were added to 50,000 allogeneic $\mathrm{MNC}$, and the resulting $\mathrm{T}$-cell proliferation was measured as $\left[{ }^{3} \mathrm{H}\right] \mathrm{TdR}$ incorporation. Results are expressed as mean $\mathrm{cpm} \pm \mathrm{SEM}$ of triplicate wells from a representative experiment.

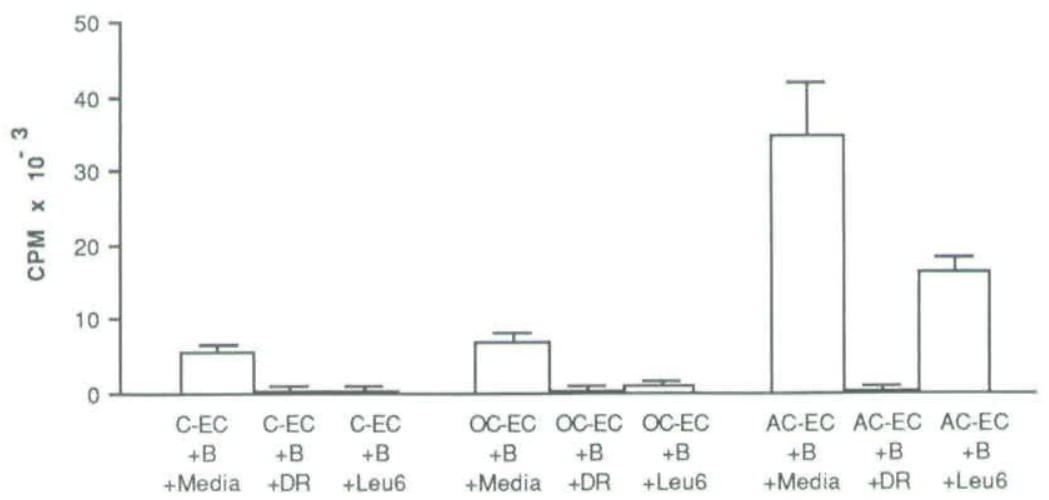

FIG. 4. Stimulation of 50,000 allogeneic MNC by 40,000 unchallenged epidermal cells (C-EC), vehicle-challenged epidermal cells (OC-EC), or hapten-challenged epidermal cells (AC-EC). The epidermal cells were treated with (1) magnetic beads + media alone $(+\mathrm{B}+$ media); (2) anti-HLA-DR and magnetic beads $(+\mathrm{B}+\mathrm{DR})$; and (3) Leu6 and magnetic beads $(+B+$ Leu6). Data are expressed as mean cpm \pm SEM of triplicate wells from a representative experiment.

The capacity of allergen-challenged skin to activate $T$ cells is dependent on both $C D I^{+} D R^{+}$ Langerhans cells and $\mathrm{CDI}^{-} \mathrm{DR}^{+}$antigenpresenting cells

The discovery of the presence of non-Langerhans $\mathrm{DR}^{+}$epidermal cells in hypersensitivity reactions raises the possibility that non-Langerhans antigen-presenting cells may participate in the epidermal antigen presentation during an allergic skin reaction. To assess the functional antigen-presenting capacity of the non-Langerhans epidermal cells at day 4 , we removed cells expressing CD1 (CD1 ${ }^{+} \mathrm{DR}^{+}$Langerhans cells) by incubation with Leu6 antibody plus Dynabeads, or cells expressing DR $\left(\mathrm{CDI}^{+}{ }^{+} \mathrm{DR}^{+} \mathrm{Lan}-\right.$ gerhans cells and $\mathrm{CD}^{-}{ }^{-} \mathrm{DR}^{+}$non-Langerhans epidermal cells) by incubation with anti-HLADR plus Dynabeads. This decreased the number of $\mathrm{CDI}^{+}$or $\mathrm{DR}^{+}$epidermal cells to undetectable levels. Depletion of $\mathrm{CDI}^{+}\left(\mathrm{CDI}^{+} \mathrm{DR}^{+}\right.$Langerhans cells) resulted in only partial abrogation of 


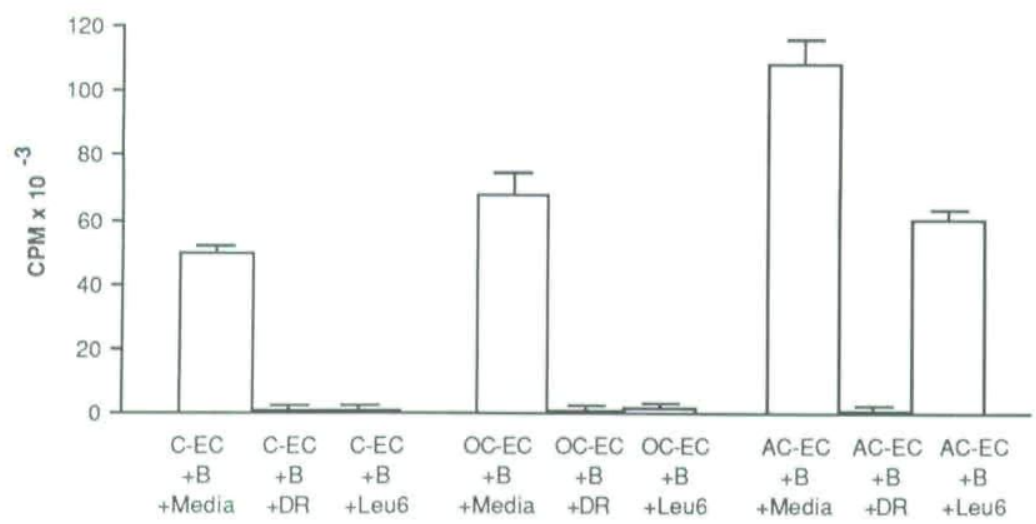

FIG. 5. Stimulation of 100,000 autologous $T$ cells by 40,000 unchallenged epidermal cells (C-EC), vehicle-challenged epidermal cells (OC-EC), or hapten-challenged epidermal cells (AC-EC). The epidermal cells were treated with (1) magnetic beads $(+\mathrm{B}+$ media); (2) anti-HLA-DR and magnetic beads $(+B+D R)$; and (3) Leu6 and magnetic beads $(+B+$ Leu6). Data are expressed as mean $\mathrm{cpm} \pm \mathrm{SEM}$ of triplicate wells from a representative experiment.

the epidermal antigen presentation capacity. In contrast, depletion of all $\mathrm{DR}^{+}$epidermal cells resulted in total abrogation of the epidermal alloantigen presentation capacity (AC-EC) (Fig. 4). This was not the result of incomplete removal of $\mathrm{CDI}^{+}$cells since depletion of $\mathrm{CDI}^{+}$cells contained within unchallenged (C-EC) or vehiclechallenged (OC-EC) epidermal cells totally abrogated the epidermal antigen-presenting function (Fig. 4). Similar results were obtained when autologous responder $\mathrm{T}$ cells were used, indicating that $\mathrm{CD}^{-} \mathrm{DR}^{+}$non-Langerhans antigenpresenting cells can present both alloantigens and autologous/nominal antigens (Fig. 5). In two experiments 33 and $53 \%$ of the total antigenpresenting cell activity of 40,000 epidermal cells was provided by non-Langerhans antigen-presenting cells (Fig. 4).

\section{DISCUSSION}

The Langerhans cell is the only known antigenpresenting cell in normal human epidermis, and its role as an antigen-processing cell in the induction of positive immune responses to antigen introduced through the skin is well established $[14,21,31,32]$. However, the epidermal cellular sources for antigen presentation in the induction phase of allergic contact dermatitis reactions are less clear. Irradiation of sensitized individuals in vivo with a single dose of UVB radiation sufficient to abrograte the function of Langerhans cells did not change the immune reactivity of the skin to subsequent challenge with antigen [27]. This could be explained by rapid recovery of epidermal Langerhans cells following the irradiation. However, normally more than 1 week is needed for recovery of epidermal Langerhans cells following in vivo UVB exposure [10]. Therefore, although the Langerhans cell is the critical antigen-presenting cell in the sensitization phase of the contact hypersensitivity response, epidermal non-Langerhans antigen-presenting cells could, in addition to Langerhans cells, play a role in the induction phase. In accordance with others we found an increased number of epidermal Langerhans cells following the contact hypersensitivity reactions [9, 13]. However, in addition to the increased number of Langerhans cells, a non-Langerhans antigen-presenting cell subtype appeared. These cells were distinct from the Langerhans cells in that they were smaller, non-dendritic, and they lacked the CDI determinant and expressed the blood monocyte antigen defined by the monoclonal antibody OKM5. The majority of the $\mathrm{OKM} 5^{+}$epidermal cells lacked expression of OKMI and therefore are analogous to a minor subpopulation $(<5 \%)$ of OKM1-OKM5+ blood monocytes which are uniquely capable of activating autoreactive immunoregulatory $\mathrm{T}$ cells [25] which may be important for down-regulation of immune responses $[15,20,23,28]$. All $\mathrm{CDl}^{-} \mathrm{OKM}^{+} \mathrm{DR}^{+}$ 
$\mathrm{OKM} 5{ }^{+} \mathrm{DR}+$ epidermal cells expressed the common leucocyte antigen, CD45, demonstrating their bone marrow origin. Keratinocytes in allergic skin reactions can express both HLA-DR and OKM5 [19, 26, 33]. These molecules are probably induced by gamma interferon and other lymphokines released from local activated T cells [6]. We did not detect any $\mathrm{HLel}^{-} \mathrm{DR}^{+}$or HLe1- ${ }^{-}$KKM $5^{+}$epidermal cells. This is probably because of the weak hypersensitivity reaction induced and the consequently minimal $\mathrm{T}$-cell infiltration and lymphokine release.

Concomitantly with the increase in number of $\mathrm{CDI}^{+} \mathrm{DR}^{+}$Langerhans cells and $\mathrm{CD}^{-}{ }^{-} \mathrm{DR}^{+}$ epidermal cells there was an increase in the antigen-presenting capacity of hapten-challenged epidermal cells. This enhanced capacity could result from either the increased number of Langerhans cells, the increased number of nonLangerhans cell DR ${ }^{+}$epidermal cells, or both. In order to determine the relative contribution of the two different types of $\mathrm{DR}^{+}$epidermal cells, $\mathrm{CDI}^{+}$ or $\mathrm{DR}^{+}$epidermal cells were depleted from the stimulator population prior to culture with $T$ cells. Depletion of $\mathrm{CD}^{+}{ }^{+}$cells $\left(\mathrm{CD}{ }^{+}{ }^{+} \mathrm{DR}^{+} \mathrm{Lan}-\right.$ gerhans cells) from unchallenged or petrolatumchallenged epidermal cells totally abrogated the antigen-presenting cell function. In contrast, depletion of autologous $\mathrm{CDI}^{+}$epidermal cells obtained 4 days after challenge with hapten only decreased the antigen-presenting cell function by 77 and $47 \%$ in two different patients. Depletion of $\mathrm{DR}^{+}$epidermal cells $\left(\mathrm{CD} 1^{+} \mathrm{DR}+\right.$ Langerhans cells and $\mathrm{CD}^{-} \mathrm{DR}^{+}$epidermal cells) totally abrogated T-cell activation. Thus, at day 4,33 or $53 \%$ of the capacity of epidermal cells to activate $\mathrm{T}$ cells may be provided by non-Langerhans antigen-presenting cells.

The function of the heterogeneous population of $\mathrm{CD} 1-\mathrm{DR}^{+}$non-Langerhans antigen-presenting cells in contact hypersensitivity skin reactions and irritant reactions [18] is unknown. They may function to enhance the ongoing immune response by presenting nominal antigen to primed $\mathrm{T}$ cells. However, they may also be analogous to the $\mathrm{CDI}^{-} \mathrm{OKM}^{+}{ }^{+} \mathrm{DR}^{+}$antigen-presenting cell subtype that appears in human skin in response to certain wavelengths of UV irradiation $[1,2,3,5$, $10,11]$. This UV-induced antigen-presenting cell population activates suppressor T-cell pathways and may function to down-regulate immune responses $[2,4]$. Thus, the non-Langerhans antigen-presenting cells may represent a negative feedback mechanism down-regulating the inflammatory reaction in contact dermatitis.

Whether these non-Langerhans cells belong to the monocyte or Langerhans cell lineage is unknown. In cutaneous T-cell lymphoma $\mathrm{CD} 1{ }^{+} \mathrm{OKM} 5{ }^{+} \mathrm{DR}{ }^{+}$non-Langerhans cells are present in the epidermis. However, these cells lack Birbeck granules [17]. Thus, the CD1- OKM5 ${ }^{+}$ epidermal cells may be precursors to Langerhans cells and in the epidermal environment they may lose their OKM5 expression and gain CDI and Birbeck granules. However, they may also be distinct from the Langerhans cell lineage.

\section{ACKNOWLEDGMENTS}

This study was supported in part by the Babcock Foundation, USA (O.B.), the Danish Medical Research Council (O.B.), and Aage Bang's Foundation, Copenhagen, Denmark (S.L., G.L.V.).

\section{REFERENCES}

1 Baadsgaard, O.. Cooper, K.D.. Lisby, S., Wulf, H.C. \& Wantzin, G.L. Dose response and time course for induction of T6-DR ${ }^{+}$human epidermal antigen presenting cells by in vivo UVA, UVB and UVC irradiation. J. Am. Acad. Dermatol. 17, 792, 1987.

2 Baadsgaard, O., Fox, D. \& Cooper, K.D. Human epidermal cells from ultraviolet light-exposed skin potently activate autoreactive $\mathrm{CD} 4+2 \mathrm{H} 4+$ suppressor inducer lymphocytes and $\mathrm{CD} 8{ }^{+}$suppressor/ cytotoxic lymphocytes. J. Immunol. 140, 1738, 1988.

3 Baadsgaard, O., Lisby, S., Vejlsgaard, G.L., Wulf, H.C. \& Cooper, K.D. Rapid recovery of Langerhans cell alloreactivity, without induction of autoreactivity, after in vivo Ultra Violet A, but not Ultra Violet B exposure of human skin. J. Immunol. 142, 4213, 1989.

4 Baadsgaard, O., Mannie, A., Dass, B., Fox, D. \& Cooper, K.D. Increased T-suppressor cell activity in humans after stimulation by UV-exposed epidermal cells: Involvement of the $2 \mathrm{H} 4$ molecule. Clin. Res. 36, 631A, 1988

5 Baadsgaard, O., Wulf, H.C., Wantzin, G.L. \& Cooper, K.D. UVB and UVC, but not UVA. potently induce the appearance of T6-DR ${ }^{+}$antigenpresenting cells in human epidermis. J. Invest. Dermatol. 89, 113, 1987.

6 Basham, T.Y., Nickoloff, B.J. \& Merigan, T.C. Recombinant gamma interferon induces HLA-DR expression on cultured keratinocytes. J. Invest. Dermatol. 83, 88, 1984.

7 Braathen, L.R. Studies on human epidermal Langerhans cells. III. Induction of T-lymphocyte 
response to nickel sulphate in sensitized individuals. Br. J. Dermatol. 103, 517, 1980.

8 Braathen, L. \& Kaamen, T. Human epidermal Langerhans cells induce cellular immune response to trichophytin in dematophytosis. Br.J. Dermatol. 204, 295, 1983

9 Christensen, O.B., Daniels, T.E. \& Maibach, H.I. Expression of OKT6 antigen by Langerhans cells in patch test reactions. Contact Dermatitis 14, 26, 1986.

10 Cooper, K.D., Fox, P.F. \& Katz, S.I. Effects of ultraviolet radiation on human epidermal cell alloantigen presentation: Initial depression of Langerhans cell function is followed by the appearance of T6-DR ${ }^{+}$cells which enhance epidermal alloantigen presentation. J. Immunol. 134, 129, 1984.

11 Cooper, K.D., Neises, G. \& Katz, S.I. Antigen presenting $\mathrm{OKM}^{+}$melanophages appear in human epidermis after ultraviolet radiation. $J$. Invest. Dermatol. 84, 370, 1986.

12 Fithian, E., Kung, P., Goldstein, G., Rubenfeld, M., Fenoglio, C. \& Edelson, R. Reactivity of Langerhans cells with hybridoma antibody. Proc. Natl. Acad. Sci. USA 78, 2541, 1981.

13 Gawkrodger, D.J., McVittie, E., Carr, M.N., Ross, J.A. \& Hunter, J.A.A. Phenotypic characterization of the early cellular responses in allergic and irritant contact dermatitis. Clin Exp. Immunol. 66, 590 , 1986.

14 Inaba, K., Schuler, G., Withmer, M.D., Valinsky, J., Atassi, B. \& Steinman. R.M. Immunologic properties of purified epidermal Langerhans cells. $J$. Exp. Med. 164, 605, 1986.

15 James, S.P., Yenokida, G.G., Graeff, A.S., Elson, C.O. \& Strober, W. Immunoregulatory function of $\mathrm{T}$ cells activated in the autologous mixed lymphocyte reaction. $J$. Immunol. 127, 2605, 1981.

16 Klareskog, L., Tjernlund, U.M., Forsum, U. \& Peterson, P.A. Ia antigen expression on human epidermal Langerhans cells. Nature 268, 247, 1977.

17 Lisby, S., Baadsgaard, O., Cooper, K.D., Hansen, E.R., Mehregan, D., Thomsen, K. \& Vejlsgaard, G.L. Phenotype, ultrastructure and function of $\mathrm{CDI}^{+} \mathrm{DR}^{+}$epidermal cells that express CD36 (OKM5) in cutaneous T cell lymphoma. Scand. J. Immunol. 32, 111, 1990.

18 Lisby, S., Baadsgaard, O., Cooper, K.D. \& Wantzin, G.L. Decreased number and function of epidermal antigen presenting cells in the skin following application of irritant agents: Relevance to cutaneous tumors? J. Invest. Dermatol. 92, 842, 1989.

19 Lisby, S., Ralfkiær, E., Hansen, E.R., Vejlsgaard, G.L. Keratinocyte and epidermal leukocyte expression of CD36 (OKM5) in benign and malignant skin diseases. Acta Derm. Venereol. 70, 18, 1990.

20 Miyasaka, N., Sauvezie, B., Pierce, D.A., Daniels, T.E. \& Talal, N. Decreased autologous mixed lymphocyte reaction in Sjogren's syndrome. J. Clin. Invest. 66, 928, 1978.

21 Ptak, W., Roxychka, D., Askenase, P. \& Gershon.
R. Role of antigen presenting cells in the development and persistence of contact hypersensitivity. $J$. Exp. Med. 51, 362, 1980.

22 Rowden, G., Lewis, M.G. \& Sullivan, A.K. La antigen expression on human epidermal Langerhans cells. Nature 268, 245, 1977.

23 Sakane, T., Steinberg, A.D. \& Green, I. Failure of autologous mixed lymphocyte reactions between $\mathrm{T}$ and non-T cells in patients with systemic lupus erythematosus. Proc. Natl. Acad. Sci. USA 75, 419, 1978.

24 Sauder, D.N., Tamaki, K., Moshell, A.N., Fujiwara, H. \& Katz, S.I. Induction of tolerance to topically applied TNCB using TNP-conjugated ultraviolet light-irradiated epidermal cells. J. Immunol. 127, 261, 1981.

25 Shen, H.H., Talle, M.A., Goldstein, G. \& Chess, L. Functional subsets of human monocytes defined by monoclonal antibodies: A distinct subset of monocytes contain the cells capable of inducing the autologous mixed lymphocyte culture. J. Immunol. 130, 698, 1983.

26 Simon Jr, J. \& Hunyadi, J. Expression of OKM5 antigen on human keratinocytes in positive intracutaneous tests for delayed-type hypersensitivity, Dermatologica 175, 121, 1987.

27 Sjovall, P., Christensen, O.B. \& Moller, H. Single exposure to ultraviolet irradiation and elicitation of human allergic contact dermatitis. Acta Derm. Venereol. (Stockholm) 65, 93, 1985.

28 Smith, J.B. \& Knowlton, R. Activation of suppressor T-cells in human autologous mixed lymphocyte culture. J. Immunol. 123, 419, 1979.

29 Stingl, G., Tamaki, K. \& Katz, S.I. Origin and function of epidermal Langerhans cells. Immunol, Rev. 53, 150, 1980.

30 Sullivan, S., Bergstresser, P., Tigelaar, R.E. \& Streilein, J.W. Induction and regulation of contact hypersensitivity by resident, bone marrow-derived, dendritic epidermal cells: Langerhans cells and Thy $-1^{+}$epidermal cells. J. Immunol. 137, 2460, 1986.

31 Tamaki, K., Fujiwara, H. \& Katz, S.I. The role of epidermal cells in the induction and suppression of contact sensitivity. J. Invest. Dermatol. 76, 275, 1981.

32 Toews, G., Bergstresser, P., Streilein, J. \& Sullivan, $\mathrm{S}$. Epidermal Langerhans cell density determines whether contact hypersensitivity or unresponsiveness follows skin painting with DNFB. J. Immunol. 124, 445, 1980.

33 Volc-Plazer, B., Majdic, O., Knapp, W., Wolff, K.. Minterberger, W., Lechner, K. \& Stingl, G. Evidence of HLA-DR antigen biosynthesis by human keratinocytes in disease. J. Exp. Med. 159, 1784, 1984.

Received 17 January 1990

Accepted in revised form 28 March 1990 
This document is a scanned copy of a printed document. No warranty is given about the accuracy of the copy. Users should refer to the original published version of the material. 